\title{
Changes in Soil Carbon Fractions and Enzyme Activities Under Different Vegetation Types of the Northern Loess Plateau
}

\author{
Haiyan Wang ${ }^{1}$, jiangqi wu ${ }^{1}$, Guang $\mathrm{Li}^{1}$, and Lijuan Yan $^{1}$ \\ ${ }^{1}$ Affiliation not available
}

June 26, 2020

\begin{abstract}
Restoring vegetation can effectively reduce soil erosion and significantly improve soil properties and quality. To analyze the response of soil organic carbon components and related enzymes to different vegetation types in the northern Loess Plateau, we collected soil samples of four vegetation types: Xanthoceras sorbifolia (XS), Hippophae rhamnoides (HR), Caragana korshinskii (CK), and Grassland (GL). We used these samples to analyze the organic carbon components (i.e., soil organic carbon (SOC), microbial biomass carbon (MBC), easily oxidized carbon (EOC), particulate organic carbon (POC) )and enzyme activities (i.e., amylase, catalase, urease and sucrase). We found that the content of the soil organic carbon fractions and the enzyme activities was greater in the upper layer than in the lower layer for each vegetation type except for MBC and catalase activity, where we observed no significant difference between soil layers. The EOC and amylase of GL vegetation were significantly higher than in other vegetation types. POC, SOC, urease and sucrase were considerably higher in SX vegetation than in other vegetation types. The maximum soil MBC content was found in $\mathrm{HR}$ vegetation, and among the four vegetation types, MBC content varied significantly differences in the lower layer, but no significant difference was observed in the surface soil. Correlation analysis demonstrated that the MBC content significantly influenced urease and sucrase activities, and that SOC significantly influenced urease and sucrase activities. These results emphasize the importance of the organic components of soil and the activities of soil enzymes in different kinds of vegetation in the Loess Plateau, providing a basis for improving the sustainable restoration of vegetative ecosystems.
\end{abstract}

Changes in Soil Carbon Fractions and Enzyme Activities Under Different Vegetation Types of the Northern Loess Plateau

Haiyan Wang ${ }^{1}$ and Jiangqi $\mathrm{Wu}^{1}$, Guang $\mathrm{Li}^{1{ }^{1,}}$ Lijuan $\mathrm{Yan}^{2}$

${ }^{1}$ College of Forestry, Gansu Agricultural University, Lanzhou, 730070, China.

${ }^{2}$ College of Agriculture, Gansu Agricultural University, Lanzhou, 730070, China.

*Correspondence: liggsau@foxmail.com.

Abstract: Restoring vegetation can effectively reduce soil erosion and significantly improve soil properties and quality. To analyze the response of soil organic carbon components and related enzymes to different vegetation types in the northern Loess Plateau, we collected soil samples of four vegetation types: Xanthoceras sorbifolia (XS), Hippophae rhamnoides(HR), Caragana korshinskii (CK), and Grassland (GL). We used these samples to analyze the organic carbon components (i.e., soil organic carbon (SOC), microbial biomass carbon (MBC), easily oxidized carbon (EOC), particulate organic carbon (POC)) and enzyme activities (i.e., amylase, catalase, urease and sucrase). We found that the content of the SOC fractions and the enzyme activities was greater in the upper layer than in the lower layer for each vegetation type except for MBC and catalase activity, where we observed no significant difference between soil layers. The EOC and amylase of GL vegetation were significantly higher than in other vegetation types. POC, SOC, urease and 
sucrase were considerably higher in SX vegetation than in other vegetation types. The maximum soil MBC content was found in $\mathrm{HR}$ vegetation, and among the four vegetation types, MBC content varied significantly differences in the lower layer, but no significant difference was observed in the surface soil. Correlation analysis demonstrated that the MBC content significantly influenced urease and sucrase activities, and that SOC significantly influenced urease and sucrase activities. These results emphasize the importance of the organic components of soil and the activities of soil enzymes in different kinds of vegetation in the Loess Plateau, providing a basis for improving the sustainable restoration of vegetative ecosystems.

Keywords:Vegetation types; Soil organic carbon components; Enzyme Activities; Loess Plateau

\section{Introduction}

Soil organic carbon (SOC) can reflect soil health, and plays an extremely important role in increasing soil carbon storage, improving soil fertility, and promoting plant growth (Sollins et al., 2007; Li et al., 2018). However, the SOC group consists of sub-groups with variable turnover rates, each with a different sensitivity to environmental changes (Guo, Wang, Wang, Wu, \& Cao, 2018). Soil active organic carbon typically includes microbial biomass carbon (MBC), easily oxidized carbon (EOC) and particulate organic carbon (POC). While the proportion of soil active organic carbon to soil total organic carbon is low, this ration can reflect the changes in soil carbon groups due to soil management measures and environmental changes (Jha et al., 2012; Sahoo, Singh, Gogoi, Kenye, \& Sahoo, 2019). The soil active organic carbon is directly involved in the biological and chemical conversion process of soil (Sun et al., 2014), plays a vital role in the cycling of soil nutrient, and stores soil nutrients (Simard, Fyles, D, \& Nguyen, 2001). Furthermore, soil active organic carbon is easily affected by plants and microorganisms in a significant way (Chen, Zhou, \& Xiao, 2010; Kimura, Murase, \& Lu, 2004). However, variation in soil active organic carbon contents across different vegetation types is poorly understood.

Soil enzyme activities are involved in the biochemical processes of the soil system and are linked to "plant-soil enzymes-soil nutrients" (Araújo et al., 2013; da Silva et al., 2012; Lino et al., 2015; Nannipieri et al., 2012). In particularly, enzyme activities (i.e., amylase, catalase, urease and sucrase) related to the soil carbon cycle and serve as important indicators of soil fertility. Amylase and sucrase are involved in the conversion of soil carbohydrates and can hydrolyze organic matter into glucose and sucrose for plant growth and microbial activity (Xie et al., 2017; Ge et al., 2011). Urease acts on carbon-nitrogen bonds in organic matter, and produces carbon dioxide and water by hydrolyzing ammonia or amino salts, while catalase is related to the redox ability of the soil (Baddam et al., 2016; Nowak et al., 2004). These enzyme activities have an important influence on the carbon cycles in soil ecosystems (Bergstrom et al., 1999; Burns et al., 2013). Previous studies have shown that plants can not only directly influence soil enzyme activities by secreting exogenous enzymes, but also affect the composition and diversity microbial species by releasing exudate and oxygen into the rhizosphere, which indirectly affect enzyme activity (Singh \& Kumar, 2008). Moreover, plants also indirectly mediate enzyme activities in the soil by controlling the volume of aboveground litter (Caravaca, Alguacil, Torres, \& Roldán, 2005). Therefore, these enzyme activities were often chosen to understand the variations in SOC and soil quality (Acosta-Martínez et al., 2007; Chen et al., 2016).

The Loess Plateau is located in the north-central China and has one of the highest concentration of loess on earth, with a total area of 64,000 square kilometers. It also has a high rate of soil erosion and is one of the most ecologically fragile environments in the world, meaning vegetation is important to enhance fertility levels and the soil's ability to hold water (García, Hernández, \& Costa, 1994). Over the past few decades, extensive efforts at restoring the environment have improved the fragile natural ecosystems on the Loess Plateau (Intergovernmental Panel on Climate Change, 2014). Vegetation restoration not only benefit for water preservation and reduction of soil erosion (Ran, $\mathrm{Lu}, \& \mathrm{Xu}, 2013$ ), but significantly improve the properties and quality of soil (Zhang et al., 2019). Studies have shown that returning farmland to forests not only improves the SOC reserves and quality, but also improves the conversion trend of soil SOC-related fractions (Deng et al., 2019; Xun et al., 2010; Liu et al., 2014). However, due to a difference in vegetation types, environmental factors, and regional variation, there is a lack of information on the relationship between enzyme activities and soil carbon fractions across different vegetation types. Therefore, we selected vegetation from forests 
(Xanthoceras sorbifolia), shrublands (Hippophae rhamnoides and Caragana korshinskii), and grasslands on the Loess Plateau to study the distribution characteristics of soil active organic carbon components and soil enzyme activities under different vegetation types. This provided a reference value for the sustainable ecological restoration of the Loess Plateau and subsequent improvement of the soil. We hypothesized that both SOC components and enzyme activities in the forest were higher than that of shrublands and grasslands, and that the SOC components and enzyme activities in the surface layer of all vegetation types were higher than in the lower layer. This study provides additional insight into nutrient cycling processes in the ecological restoration of vegetation, and improves the sustainability of ecosystem restoration by identifying effective vegetation to plant.

\section{Materials and methods}

\subsection{Site description}

The study area $\left(103^{\circ} 52^{\prime}-105 \operatorname{deg} 13^{\prime}\right.$ E, 34deg26'-35deg35' N) is located in the middle of Gansu Province in northwest China (Fig. 1) and possesses the hills and gullies typical of the middle of the Loess Plateau. Its average elevation is about $1947 \mathrm{~m}$. It has a semi-arid climate and average annual precipitation of about $390.99 \mathrm{~mm}$, which falls mostly from July to September following the harvest season. The soil is a typical loess soil, which is soft and prone to erosion. In recent decades, large-scale vegetation restoration was implemented by the government to address ecological degradation. As such, a large area of sloped cropland was replanted with trees and shrubs. The major tree species planted during each period of reforestation are Xanthoceras sorbifolia ,Caragana korshinskii, and Hippophae rhamnoides. Xanthoceras sorbifolium is a promising bioenergy crop as its seed oil is a suitable feedstock for biodiesel. It belongs to theXanthoceras Bunge (Sapindaceae Juss. ) and is a unique woody oil tree species unique to China with a planting area of more than 170000 ha (Ma et al., 2020). Caragana korshinskii is a cultivated leguminous shrub belonging to the legume. Its unique stress resistance characteristics make it an important forage, industrial raw material and afforestation species, with various economic and ecological values (Zhang et al., 2009). Hippophae rhamnoides belongs to the family Hippophae rhamnoides. It has the characteristics of drought tolerance, cold tolerance and barren tolerance. It is one of the few tree species that can grow in the forest zone, forest steppe zone and typical steppe zone at the same time. Sea buckthorn berries have been used as traditional medicine for a long time due to their richness in various bioactive ingredients (Sharma et al., 2019; Wei et al., 2019).

\subsection{Experimental design and soil sampling}

In the experimental site, the grassland (GL; Area: $30 \mathrm{~m} \mathrm{x} 40 \mathrm{~m}$; 35deg34'54"N, 104deg37'57"E) was the control group, while Xanthoceras sorbifolia (XS; Area: $20 \mathrm{~m}$ x $50 \mathrm{~m}$; 35deg35'10"N, 104deg37'7"E), Caragana korshinskii (CK; Area: $30 \mathrm{~m}$ x $30 \mathrm{~m}$; 35deg34'55"N, 104deg38'1"E), and Hippophae rhamnoides (HR; Area: $20 \mathrm{~m} \times 30 \mathrm{~m}$; 35deg34'45"N, 104deg39'1"E) were designated as the three vegetation types (Table 1). Three sample plots (with the size of $8 \mathrm{~m} \mathrm{x} 8 \mathrm{~m}$ ) were randomly selected from each vegetation type for sampling.

In September 2017, the soil sampler (diameter $5 \mathrm{~cm}$ ) was used to sample layers $(0-20,20-40 \mathrm{~cm}$ ) according to the diagonal 5-point method (four points were selected at both ends of an "X", with one point selected at the intersection). Five soil samples of the same soil layer in each plot were mixed to form one soil sample for a total of 24 soil samples. After removing debris, such as stones and residual roots, the sample was divided into two parts. One part of the fresh soil was stored in a refrigerator at $4 \mathrm{degC}$ through a $2 \mathrm{~mm}$ soil sieve. Another part of the soil was air-dried (direct sunlight was avoided on soil samples), placed in a ziplock bag through a 100-mesh soil sieve, and stored in a cool and ventilated place (storage time not exceeding one year).

\subsection{Soil carbon fractions}

SOC was determined by the Walkley-Black dichromate oxidation method (Nelson, 1982), using a mixture of potassium dichromate $\left(\mathrm{K}_{2} \mathrm{Cr}_{2} \mathrm{O}_{7}\right)$ and sulfuric acid $\left(\mathrm{H}_{2} \mathrm{SO}_{4}\right)$ to oxidize the organic matter, after which it was titrated against ferrous sulfate $\left(\mathrm{FeSO}_{4}\right)$. The air-dried soil sample $(0.1 \mathrm{~g})$ was extracted with $7.5 \mathrm{ml}$ of 
$\mathrm{K}_{2} \mathrm{Cr}_{2} \mathrm{O}_{7}$ and $7.5 \mathrm{ml}$ of concentrated $\mathrm{H}_{2} \mathrm{SO}_{4}$ at $180 \operatorname{deg} \mathrm{C}$ for $30 \mathrm{~min}$.

MBC was determined on fresh soil samples (sieving $<2 \mathrm{~mm}$ ) using the chloroform fumigation-extraction method (Vance, Brookes, \& Jenkinson, 1987). The fumigated and non-fumigated soil ( $5 \mathrm{~g}$, accurate to 0.001 g) were extracted with $20 \mathrm{ml} 0.5 \mathrm{M}$ of $\mathrm{K}_{2} \mathrm{SO}_{4}$ for $30 \mathrm{~min}$ on a shaker $(180 \mathrm{r} / \mathrm{min}) .5 \mathrm{ml}$ of supernatant was extracted and titrated according to the method of organic carbon. MBC was calculated as (C fumigated-C non-fumigated)/0.38 (McLatchey \& Reddy, 1998).

POC was determined with necessary modifications based on the method described by Yang (Yang et al., 2009). Twenty grams of the soil were dispersed with $100 \mathrm{~mL}$ of a $5 \mathrm{~g} / \mathrm{L}$ sodium hexametaphosphate solution by hand shaking the mixture for $15 \mathrm{~min}$ and placing it on a reciprocal shaker $(100 \mathrm{r} / \mathrm{min})$ for $16 \mathrm{~h}$. The dispersed soil sample was then passed through a $53 \mu \mathrm{m}$ sieve and rinsed thoroughly with distilled water. The remaining material was dried at $50^{\circ} \mathrm{C}$, weighed and finely ground.

EOC was measured by slightly modifying the light group organic compound separation method using $\mathrm{KMnO}_{4}$ oxidation (Janzen et al.,1992).

\subsection{Soil enzymes activities}

Soil catalase activity was determined using the potassium permanganate titration (Guan, 1986; Li et al., 2014). $40 \mathrm{ml}$ of distilled water and $5 \mathrm{ml}$ of hydrogen peroxide solution (3\%) were added to $2 \mathrm{~g}$ of soil, which was shaken for $30 \mathrm{~min}$ and then filtered. We then took $25 \mathrm{ml}$ of the filtrate and titrated it to pink with 0.1 M potassium permanganate.

The urease activities were analyzed according to the methods used by Guan and Yin (Guan,1986; Yin et al, 2014). The soil (2 g) was treated with $10 \mathrm{ml}$ urea (10\%), $20 \mathrm{ml}$ citrate buffer $(1 \mathrm{M}, \mathrm{pH} 6.7)$, and $1 \mathrm{ml}$ of methylbenzene and stored at room temperature for $15 \mathrm{~min}$. The sample was then shaken at 37 for $24 \mathrm{~h}$. The solution was filtered, and $1 \mathrm{ml}$ of the filtrate was mixed with $20 \mathrm{ml}$ of distilled water, $4 \mathrm{ml}$ of sodium phenolate hydroxide, and $3 \mathrm{ml}$ of sodium hypochlorite. The $\mathrm{NH}_{4}{ }^{+}-\mathrm{N}$ was analyzed 20 minutes later using a spectrophotometer at $578 \mathrm{~nm}$. Urease activity was expressed in milligrams of $\mathrm{NH}_{4}{ }^{+}-\mathrm{N}$ per gram of dry soil released in $24 \mathrm{~h}$.

The invertase activity and amylase enzyme activities were analyzed according to the methods used by Guan (Guan, 1986), using 3, 5-dinitrosalicylic acid, the invertase activity and amylase activities were measured using sucrose solution and soluble starch as respective substrates, respectively. The invertase activity was expressed as the mass $(\mathrm{mg})$ of glucose in $1 \mathrm{~g}$ of soil after $24 \mathrm{~h}$; the amylase activity was expressed as the mass $(\mathrm{mg})$ of maltose in $1 \mathrm{~g}$ of soil after $24 \mathrm{~h}$.

\subsection{Statistical analysis}

We used the Tukey-Kramer method to analyze significant differences in the soil carbon component content and enzyme activity under different vegetation types. A two-way ANOVA test was used to analyze the effects of vegetation type and soil layer depth on the SOC components and enzyme activities. The confidence interval was $95 \%$, and $\mathrm{P}<0.05$ was considered significant. The errors in the figures and tables of this article are standard errors. The relationships between soil catalase, sucrase, amylase, urease and soil carbon fractions were analyzed using a Pearson correlation analysis.

\section{Results}

\subsection{Variation of soil physical and chemical properties in different vegetation types}

The type of vegetation had significant effects on the soil's basic physical and chemical properties. The bulk density of the 0-20 cm CK soil layer was significantly lower than both in HR and GL (Table 2). The soil bulk density of the CK plot in the 20-40 cm layer was the smallest, but the difference has not reached a significant level. Moreover, the contents of total N and total P in the XS 0-20 cm layer were significantly higher than those in the other three vegetation types $(\mathrm{P}<0.05)$. The maximum total $\mathrm{N}$ content of the soil in the 20-40 cm layer appeared in the HR plot, and the maximum total P content appeared in the GL plot, 
but the difference in vegetation type to soil total $\mathrm{N}$ and total $\mathrm{P}$ content did not reach a significant level. The soil bulk density of the 20-40 cm layer under all four vegetation types was higher than that in the $0-20 \mathrm{~cm}$ layer, while the total porosity, total $\mathrm{N}$ and total $\mathrm{P}$ in the $20-40 \mathrm{~cm}$ soil layer were lower than in the $0-20 \mathrm{~cm}$ layer.

\subsection{Variation of soil carbon fractions in different vegetation types}

There were significant differences in EOC, POC, and SOC under the four types of vegetation (Fig. 2). There were no significant differences in the soil MBC content among the four types of vegetation in the 0-20 cm layer. The MBC content in the 20-40 cm layer of $\mathrm{HR}$ vegetation was significantly higher than in the other three vegetation types. Except for the MBC contents of the HR vegetation, the MBC, EOC, POC, and SOC contents in other vegetation types decreased significantly as soil depth increased. At the $0-20 \mathrm{~cm}$ layer, the EOC contents of the GL vegetation was $1.44,2.82$, and $2.06 \mathrm{~g} / \mathrm{kg}$ higher than XS, HR, and CK, respectively, while at the 20-40 cm layer, the EOC contents was $0.63,1.01$, and $0.95 \mathrm{~g} / \mathrm{kg}$ higher than XS, HR, and CK, respectively. The POC and SOC contents in the 0-20 cm layer of XS vegetation were significantly higher than those in the other three vegetation types. The POC content in HR vegetation and the SOC content in GL vegetation at the $20-40 \mathrm{~cm}$ layer were the highest. The maximum values of POC and SOC were 0.37 and $1.61 \mathrm{~g} / \mathrm{kg}$ higher than the minimum values, respectively. A two-way ANOVA analysis demonstrated significant associations between soil depth and vegetation type on organic carbon components (MBC, EOC, POC and SOC) in all the samples measured (Table 3).

\subsection{Variation of soil enzyme activities in different vegetation types}

The type of vegetation significantly affected soil amylase, urease, and sucrase activities (Fig. 3). There were no significant differences in soil catalase activity among the four vegetation types. However, a two-way ANOVA test revealed a significant association between soil depth and vegetation type on catalase activity (Table 3). For the 0-20 cm soil layer, the amylase activity in GL vegetation was significantly higher than that of the other three vegetation types (Fig. 3A); the urease activity of XS vegetation was significantly higher than that of HR, CK, and GL by $58.75,69.04$, and $48.49 \mathrm{mg} / \mathrm{g}$, respectively (Fig. 3C); soil sucrase activity in GL vegetation was significantly higher than HR and CK by 110.23 and $423.35 \mathrm{mg} / \mathrm{g}$, respectively, but no significant difference was observed in XS vegetation (Fig. 3D). In the $20-40 \mathrm{~cm}$ soil layer, HR amylase activity displayed significant differences with CK, and displayed no significant differences with XS and GL. The CK amylase activity was significantly lower than the other three vegetation types. The soil urease activity in the 20-40 cm layer of XS vegetation was significantly higher than that of the other three types of vegetation. As soil depth increased, vegetation soil catalase and sucrase activities increased (except for CK). Soil enzyme activity under other vegetation types was greater in the upper layers than in the lower layers. A two-way ANOVA test demonstrated extremely significant relationships between soil depth and vegetation type on enzyme activity (amylase, urease, sucrase) in all samples studied (Table 3).

\subsection{Relationships among the SOC fractions, enzyme activities, physical and chemical charac- teristics}

A correlation analysis (Table 4) demonstrated that the MBC content displayed an extremely significant positive correlation with the POC and catalase, and displayed an extremely significant negative correlation with EOC (with a correlation coefficient of 0.911). The POC was significantly correlated with the SOC, urease, sucrase, total $\mathrm{N}$ and $\mathrm{P}$, however, no significant correlations were observed with amylase, catalase, total porosity, and bulk density. The SOC was significantly correlated with urease, sucrase, total N, total $\mathrm{P}$, total porosity, and bulk density. Soil sucrase activity displayed an extremely significant correlation with amylase and urease, with respective correlation coefficients of 0.597 and 0.848 . Physical and chemical characteristics of the soil (i.e., total $\mathrm{N}$, total $\mathrm{P}$, total porosity, and bulk density) displayed strong positive correlation with urease and surase.

4. Discussion

\subsection{Soil carbon fraction ofdifferent type vegetations}


Vegetation is one of the most important components of an ecosystem, and its community succession has a significant effect on the SOC content (Deng et al., 2018; Solomon et al., 2007). This study demonstrated that SOC content in a forest was significantly higher than in shrublands and grasslands (Fig. 2D). Root exudates and litter from forest vegetation both strongly affected the organic carbon content in the soil and promoted the effectiveness of forest nutrients (Qiao, Miao, Silva, \& Horwath, 2014). At the same time, forest vegetation can also alter the forest environment, reducing solar radiation and temperature differences, increasing soil moisture (Ozkan \& Gokbulak, 2017), and creating a stable environment for litter decomposition. All of this causes the SOC content of forest to be higher than that of shrublands and grasslands. Moreover, due to the higher coverage of herbaceous vegetation and abundant species density (Table 1), more surface litter increases the sources of organic carbon (Zhang et al., 2019), making the SOC content of desert grassland vegetation higher than that of both $\mathrm{HR}$ and $\mathrm{CK}$ vegetation. Meanwhile, the SOC content of the four vegetation types was not only due to organic carbon inputs, but was also affected by enzyme activities and soil physical-chemical characteristics. A correlation analysis between SOC contents and soil physical-chemical characteristics and enzyme activities further confirmed these results (Table 4).

The MBC content in the soil of HR was significantly higher than in the soil of GL (Fig. 2A). On the one hand, HR vegetation has a wide horizontal root structure and can quickly grow new shoots (Letchamo et al., 2018). These new shoots increase soil porosity (Table 2) and oxygen content during the growth process, and increase soil aerobic microbial activity. On the other hand, the root nodules of HR can fix atmospheric nitrogen and improve soil fertility (their annual average nitrogen accumulation is $17,475 \mathrm{~kg} / \mathrm{hm}^{2}$ ) (Ruan \& Li, 2002). Studies have shown that increasing soil N can promote microbial activity and increase the decomposition rate of soil organic matter (Nottingham et al., 2012; Sistla, Asao, \& Schimel, 2012), thereby reducing SOC content. The partial shading effect of XS vegetation reduces the soil temperature and the activity of soil microorganisms (Jimenez, Tejedor, \& Rodriguez, 2007). Therefore, the soil MBC content is highest in $\mathrm{HR}$ vegetation.

The changes in soil POC and SOC are consistent (Fig. 2C) across different types of vegetation, while the changes in EOC and SOC differ (Fig. 2B). Since the soil in this study was obtained from different types of vegetation, different physical and chemical properties (Table 2) regulate the decomposition rates in the soil (Xu et al., 2016). Various surface litter can significantly change the input of soil organic matter (Thorburn, Meier, Collins, \& Robertson, 2012), which affects the EOC content in the surface soil (DuPont, Culman, Ferris, Buckley, \& Glover, 2010). At the same time, the higher soil temperature and the lower soil water content, which may potentially create more beneficial conditions to enhance labile SOC fractions (Chen et al., 2016). However, the decomposition of plant litter is the most complex ecological process in the biosphere (Mendez, Martinez, Araujo, \& Austin, 2019). Therefore, due to the differences in tree species composition, litter quantity and quality, soil microbial group composition, soil moisture, temperature, and nutrient input, different vegetation types have significant differences in soil active organic carbon components (Yang et al., 2018; Soucemarianadin et al., 2018).

The content of activated carbon in the soil under the four vegetation types was greater in the upper layer than in the lower layer. This was mainly because the soil active organic carbon largely depends on the total organic carbon content of the soil. Total SOC decreased as soil depth increased (Fig. 2D), however, the litter on the upper layer not only provides a significant amount of organic carbon for the soil, but also provides the surface soil with a high concentration of nutrients (Table 2), providing stable conditions for growing fine roots in the topsoil layer. Litter and root exudates have become an important source of soil active organic carbon after they are decomposed by microorganisms (Weintraub, Scott-Denton, Schmidt, \& Monson, 2007).

\subsection{Soil enzyme activity of different type vegetations}

Our study shows that different vegetation types affect soil enzyme activity differently (Fig. 3). Urease, a key enzyme that regulates soil nitrogen transformation, comes mainly from plants and microbes and plays a key role in nutrient cycling (Zhao, Li, \& Wang, 2012). Soil urease activity in XS vegetation is higher than in the others (Fig. 2C). The high urease activities in XS vegetation may be due to both microbial growth and stimulation of microbial activity by enhanced resource availability (Li et al., 2014). At the same 
time, higher soil nutrients (Table 2) and SOC contents (Fig. 2D) provide microorganisms with a rich source of nitrogen and carbon, which significantly adds to the nutrients accumulated by transformation (Cui et al., 2019). Improving the physical properties of soil creates an environment that benefits microorganisms (Iovieno, Morra, Leone, Pagano, \& Alfani, 2009) and increases urease activity.

Catalase can decompose hydrogen peroxide into molecular oxygen and water to prevent cells from being damaged by reactive oxygen species (Bartkowiak \& Lemanowicz, 2017). In this study, we found no significant difference in soil catalase activity under different vegetation types. This may be due to less rainfall in this area, and small differences in soil microbial activity (MBC, Fig. 2) and soil properties (bulk density and porosity, Table 2), leading to there was no significant difference in soil catalase activity. Furthermore, microbial communities, litter decomposition, and soil $\mathrm{pH}$ are also important factors affecting soil catalase activity (Brzezińska et al., 2005; Gu et al., 2009; Kannan and Wei, 2008).

Soil amylase and cellulose enzymes are responsible for the rate and course of plant material decomposition and plant debris degradation (Piotrowska, 2014). Significant differences in soil amylase and sucrase activities were observed under the four vegetation types $(\mathrm{P}<0.05)$. The activities of amylase (Fig. 3A) and sucrase (Fig. 3D) in GL vegetation in the $0-20 \mathrm{~cm}$ layer were significantly higher than in the other three vegetation types. In the 20-40 cm layer, the soil amylase activity in the HR vegetation was the highest, while there was no significant difference in the other three vegetation types. The soil sucrase in the XS vegetation was significantly higher than that in the other three vegetation types. Because there are more types of vegetation and litter on the surface of GL, the content of SOC fractions is higher (Fig. 2), and soil organic matter has a higher input capacity, which affects the community structure and growth of rhizosphere soil microorganisms (Prescott, 2010). GL vegetation is also dominated by low, herbaceous vegetation (Table 1). The shade effect of this vegetation is small, and soil temperature is higher than in the other three vegetation types, resulting in higher soil amylase and invertase activities in GL vegetation. The higher MBC, POC contents (Fig. 2A, C), and total porosity (Table 2) in the 20-40 cm layer of HR vegetation provide a source of oxygen for microbial activity, while the root system of GL vegetation is mainly concentrated in the $0-20 \mathrm{~cm}$ layer (An, Huang, \& Zheng, 2009), meaning that amylase in HR vegetation is more active in the 20-40 cm layer.

In all four vegetation types, the soil amylase, urease, and sucrase activities were greater in the upper layer than in the lower layer, while the soil catalase activity did not change significantly. Due to the high SOC content (Fig. 2), there are sufficient nutrient sources to facilitate the growth of microorganisms. In addition, higher surface temperatures and better ventilation enable soil microorganisms to quickly grow and metabolize (Chen, Shang, Cai, \& Zhu, 2019). The underground biomass in the 20-40 cm soil layer was reduced, which reduces the source of soil nutrients, while this reduction of SOC content and plant roots often leads to a decrease in enzyme activity (Xiao, Huang, \& Lu, 2015). These results suggests that the effects of vegetation on soil enzyme activities are different under different soil types and environmental conditions.

\subsection{Relationship between soil carbon fraction and enzyme activity}

Enzymes participate in the transformation process of soil nutrients. Enzyme activity plays a vital role in soil microbial activity and soil quality (Ebhin Masto, Chhonkar, Singh, \& Patra, 2006). Under stable organic nutrient conditions, soil enzyme activity is typically higher, and increased mineralization of the soil's nutrients creates a more favorable environment for nutrient cycling (Roldán, Salinas-García, Alguacil, \& Caravaca, 2005). The results of this study demonstrate that catalase activity was significantly related to MBC content, and can reflect the changing process of MBC. Both urease activity and invertase activity displayed significant positive correlations with organic carbon and total $\mathrm{N}$ content. Urease and invertase activity can reflect the decomposition of organic matter and nitrogen in soil and can be used as important indicators of soil fertility. In sum, enzyme activity and carbon fraction influence each other's conversion and circulation of nutrients (Qi et al., 2016; S. Zhao et al., 2016).

\section{Conclusions}

This study analyzed the responses of soil organic carbon fractions and related enzyme activities to different vegetation types in the northern Loess Plateau. Our results demonstrated that the content of soil SOC, EOC 
and POC were greater in the upper layer than in the lower layer, except for MBC. This variation was similar for different vegetation types. Vegetation types effected on soil organic carbon fractions differently. The maximum $\mathrm{MBC}$ content in the upper soil was observed in $\mathrm{HR}$ vegetation, the maximum $\mathrm{EOC}$ content was observed in GL vegetation, and the soil POC and SOC contents of SX vegetation were significantly higher than in the other three vegetation types. Moreover, the type of vegetation significantly influenced soil enzyme activities, except for catalase. For all four vegetation types, the soil amylase, urease, and sucrase were all significantly higher in the upper than in the lower layer. In contrast, the soil catalase displayed no significant difference between soil layers. In addition, we also found that the MBC significantly impacted catalase activities, POC significantly impacted urease and sucrase activities, and SOC significantly impacted urease and sucrase activities. Considering that the related effects of vegetation environment on litter decomposition and soil microbial community structure will jointly affect the soil carbon dynamics under human disturbance, more long-term research is needed to better understand the dynamic mechanism of soil organic carbon fractions after returning farmland to forest.

\section{Acknowledgments}

This research was supported by the Fostering Foundation for the Excellent Ph.D. Dissertation of Gansu Agricultural University (YB2018004), and Collaborative Innovation Team Project of Higher Education Institutions in Gansu Province, China (2018C-16), Primary Research and Development Plan of Gansu Province, China (18YF1NA070), and Special Financial Gansu Province, China (GSCZZ-20160909).

\section{Conflicts of Interest}

The authors declare no conflict of interest.

\section{Author contributions}

Jiangqi Wu: experiments (design). Jiangqi Wu and Haiyan Wang: experiments (perform) and data collection. Jiangqi Wu: data analysis. Jiangqi Wu, Haiyan Wang, Guang Li and Lijuan Yan: paper writing.

\section{Data accessibility statement}

The soil organic carbon fractions and enzyme activities data in Dryad:https://doi.org/10.5061/ dryad.jwstqjq68.

\section{References}

Acosta-Martínez, V., Cruz, L., Sotomayor-Ramírez, D., \& Pérez-Alegría, L. (2007). Enzyme activities as affected by soil properties and land use in a tropical watershed. Applied Soil Ecology, 35 (1), 35-45. doi:10.1016/j.apsoil.2006.05.012

Araújo, A. S. F., Cesarz, S., Leite, L. F. C., Borges, C. D., Tsai, S. M., \& Eisenhauer, N. (2013). Soil microbial properties and temporal stability in degraded and restored lands of Northeast Brazil. Soil Biology and Biochemistry, 66 , 175-181. doi:10.1016/j.soilbio.2013.07.013

An, S. S., Huang, Y. M. \& Zheng, F. L. (2009). Evaluation of soil microbial indices along a revegetation chronosequence in grassland soils on the Loess Plateau, Northwest China. Applied Soil Ecology , 41(3), 286-292.

Baddam, R., Reddy, G.B., Raczkowski, C. and Cyrus, J.S. (2016). Activity of soil enzymes in constructed wetlands treated with swine wastewater.Ecological engineering , 91, 24-30.

Bartkowiak, A., \& Lemanowicz, J. (2017). Effect of forest fire on changes in the content of total and available forms of selected heavy metals and catalase activity in soil. Soil Science Annual, 68 (3), 140-148. doi:10.1515/ssa-2017-0017

Bergstrom, D. W., Monreal, C. M., Tomlin, A. D., Miller, J. J. (1999). Interpretation of soil enzyme activities in a comparison of tillage practices along a topographic and textural gradient. Canadian Journal of Soil 
Science, 80, 71-79.

Brzezińska, M., Włodarczyk, T., Stepniewski, W., Przywara, G. (2005). Soil aeration status and catalase activity. Acta Agrophysica ,5, 555-565.

Burns, R.G., DeForest, J.L., Marxsen, J., Sinsabaugh, R.L., Stromberger, M.E., Wallenstein, M.D., Weintraub, M.N., Zoppini, A. (2013). Soil enzymes in a changing environment: Current knowledge and future directions. Soil Biology and Biochemistry , 58, 216-234, doi:10.1016/j.soilbio.2012.11.009.

Caravaca, F., Alguacil, M. M., Torres, P., \& Roldán, A. (2005). Plant type mediates rhizospheric microbial activities and soil aggregation in a semiarid Mediterranean salt marsh. Geoderma, 124 (3-4), 375-382. doi:10.1016/j.geoderma.2004.05.010

Chen, H. L., Zhou, J. M., \& Xiao, B. H. (2010). Characterization of dissolved organic matter derived from rice straw at different stages of decay. Journal of Soils and Sediments, 10 (5), 915-922. doi:10.1007/s11368$010-0210-\mathrm{x}$

Chen, H., Shang, Z., Cai, H., \& Zhu, Y. (2019). Irrigation Combined with Aeration Promoted Soil Respiration through Increasing Soil Microbes, Enzymes, and Crop Growth in Tomato Fields. Catalysts, 9 (11), 945. doi:10.3390/catal9110945

Chen, X., Chen, H. Y., Chen, X., Wang, J., Chen, B., Wang, D., \& Guan, Q. (2016). Soil labile organic carbon and carbon-cycle enzyme activities under different thinning intensities in Chinese fir plantations. Applied Soil Ecology, 107 , 162-169. doi:10.1016/j.apsoil.2016.05.016

Cui, Y., Fang, L., Guo, X., Han, F., Ju, W., Ye, L., . . Z Zhang, X. (2019). Natural grassland as the optimal pattern of vegetation restoration in arid and semi-arid regions: Evidence from nutrient limitation of soil microbes. Sci Total Environ, 648 , 388-397. doi:10.1016/j.scitotenv.2018.08.173

da Silva, D. K. A., de Oliveira Freitas, N., de Souza, R. G., da Silva, F. S. B., de Araujo, A. S. F., \& Maia, L. C. (2012). Soil microbial biomass and activity under natural and regenerated forests and conventional sugarcane plantations in Brazil. Geoderma, 189-190 , 257-261. doi:10.1016/j.geoderma.2012.06.014

Deng, J., Chong, Y., Zhang, D., Ren, C., Zhao, F., Zhang, X., Han, X., Yang, G. (2019). Temporal Variations in Soil Enzyme Activities and Responses to Land-Use Change in the Loess Plateau, China. Applied Sciences , $9(15), 3129$.

Deng, L., Wang, K., Zhu, G., Liu, Y., Chen, L., Shangguan, Z. (2018). Changes of soil carbon in five land use stages following 10 years of vegetation succession on the Loess Plateau, China. Catena ,171 , 185-192, doi:10.1016/j.catena.2018.07.014.

DuPont, S. T., Culman, S. W., Ferris, H., Buckley, D. H., \& Glover, J. D. (2010). No-tillage conversion of harvested perennial grassland to annual cropland reduces root biomass, decreases active carbon stocks, and impacts soil biota. Agriculture, Ecosystems \& Environment, 137 (1-2), 25-32. doi:10.1016/j.agee.2009.12.021

Ebhin Masto, R., Chhonkar, P. K., Singh, D., \& Patra, A. K. (2006). Changes in soil biological and biochemical characteristics in a long-term field trial on a sub-tropical inceptisol. Soil Biology and Biochemistry, 38 (7), 1577-1582. doi:10.1016/j.soilbio.2005.11.012

Garcia, C., Hernandez, T., Costa, F. (1994). Microbial activity in soils under mediterranean environmental conditions. Soil Biology and Biochemistry, 26, 0-1191.

Ge, T., Nie, S.A., Wu, J., Shen, J., Tong, C., Huang, D., Hong, Y. and Iwasaki, K. (2011). Chemical properties, microbial biomass, and activity differ between soils of organic and conventional horticultural systems under greenhouse and open field management: a case study. Journal of Soils and Sediments , 11(1), $25-36$.

Gu, Y., Wang, P., Kong, C.H. (2009). Urease, invertase, dehydrogenase and polyphenoloxidase activities in paddy soil influenced by allelopathic rice variety. European Journal of Soil Biology, 45(5/6): 436-441. 
Guan, S. Y., Zhang, D. S., Zhang, Z. M. (1986). Soil enzyme and its research methods ; Agriculture ; Beijing, China, 274-297.

Guo, J., Wang, B., Wang, G., Wu, Y., Cao, F. (2018). Vertical and seasonal variations of soil carbon pools in ginkgo agroforestry systems in eastern China. Catena , 171 , 450-459, doi:10.1016/j.catena.2018.07.032.

Intergovernmental Panel on Climate Change (IPCC). (2014). Fifth assessment report, climate change. Synthesis report. Cambridge Univ. Press, Cambridge, UK.

Iovieno, P., Morra, L., Leone, A., Pagano, L., \& Alfani, A. (2009). Effect of organic and mineral fertilizers on soil respiration and enzyme activities of two Mediterranean horticultural soils. Biology and Fertility of Soils, 45 (5), 555-561. doi:10.1007/s00374-009-0365-Z

Janzen, H. H., Campbell, C. A., Brandt, S. A., Lafond,G. P., Townley-Smith, L. (1992). Light-Fraction Organic Matter in Soils from Long-Term Crop Rotations. Soil Science Society of America Journal, 56, 1799.

Jha, P., De, A., Lakaria, B. L., Biswas, A. K., Singh, M., Reddy, K. S., \& Rao, A. S. (2012). Soil Carbon Pools, Mineralization and Fluxes Associated with Land Use Change in Vertisols of Central India.National Academy Science Letters, 35 (6), 475-483. doi:10.1007/s40009-012-0082-2

Jimenez, C., Tejedor, M., \& Rodriguez, M. (2007). Influence of land use changes on the soil temperature regime of Andosols on Tenerife, Canary Islands, Spain. European Journal of Soil Science, 58 (2), 445-449. doi:10.1111/j.1365-2389.2007.00897.x

Kannan, I., Wei, S. (2008). Soil enzyme activities in two forage systems following application of different rates of swine lagoon effluent or ammonium nitrate. Applied Soil Ecology , 38(2): 128-136.

Kimura, M., Murase, J., \& Lu, Y. (2004). Carbon cycling in rice field ecosystems in the context of input, decomposition and translocation of organic materials and the fates of their end products $\left(\mathrm{CO}_{2}\right.$ and $\left.\mathrm{CH}_{4}\right)$. Soil Biology and Biochemistry, 36 (9), 1399-1416. doi:10.1016/j.soilbio.2004.03.006

Letchamo, W., Ozturk, M., Altay, V., Musayev, M., Mamedov, N., Hakeem, K. (2018). An alternative potential natural genetic resource: sea buckthorn [Elaeagnus rhamnoides (syn: Hippophae rhamnoides)] //Global Perspectives on Underutilized Crops. Springer, Cham, 25-82.

Li, J., Wu, X., Gebremikael, M.T., Wu, H., Cai, D., Wang, B., Li, B., Zhang, J., Li, Y. and Xi, J. (2018). Response of soil organic carbon fractions, microbial community composition and carbon mineralization to high-input fertilizer practices under an intensive agricultural system.PloS one , 13(4).

Li, Q.; Liang, J. H., He, Y. Y., Hu, Q. J, Yu, S. (2014). Effect of land use on soil enzyme activities at karst area in Nanchuan, Chongqing, Southwest China. Plant, Soil and Environment, 60(1), 15-20.

Lino, I. A. N., Santos, V. M., Escobar, I. E. C., Silva, D. K. A., Araujo, A. S. F., \& Maia, L. C. (2015). Soil Enzymatic Activity in Eucalyptus Grandis Plantations of Different Ages. Land Degradation 8 S Development, 27 (1), 77-82. doi:10.1002/ldr.2454

Liu, M., Chang, Q., Qi, Y., Liu, J., \& Chen, T. (2014). Aggregation and soil organic carbon fractions under different land uses on the tableland of the Loess Plateau of China. Catena , 115, 19-28.

Ma, Y., Bi, Q., Li, G., Liu, X., Fu, G., Zhao, Y. and Wang, L. (2020). Provenance variations in kernel oil content, fatty acid profile and biodiesel properties of Xanthoceras sorbifolium Bunge in northern China.Industrial Crops and Products , 151, 112487.

McLatchey, G. P., Reddy, K. R. (1998). Regulation of organic matter decomposition and nutrient release in a wetland soil. Journal of Environmental Quality , 27(5), 1268-1274.

Mendez, M. S., Martinez, M. L., Araujo, P. I., \& Austin, A. T. (2019). Solar radiation exposure accelerates decomposition and biotic activity in surface litter but not soil in a semiarid woodland ecosystem in Patagonia, Argentina. Plant and Soil, 445 (1-2), 483-496. doi:10.1007/s11104-019-04325-1 
Nannipieri, P., Giagnoni, L., Renella, G., Puglisi, E., Ceccanti, B., Masciandaro, G., . . . Marinari, S. (2012). Soil enzymology: classical and molecular approaches. Biology and Fertility of Soils, 48 (7), 743-762. doi:10.1007/s00374-012-0723-0

Nelson, D. W. (1982). Total carbon, organic carbon and organic matter.Methods of Soil Analysis , 9, 961-1010.

Nottingham, A.T., Turner, B.L., Chamberlain, P.M., Stott, A.W., Tanner, E.V. (2012). Priming and microbial nutrient limitation in lowland tropical forest soils of contrasting fertility. Biogeochemistry, 111(1-3), 219-237.

Nowak, J., Kaklewski, K. and Ligocki, M. (2004). Influence of selenium on oxidoreductive enzymes activity in soil and in plants. Soil Biology and Biochemistry, 36(10), 1553-1558.

Ozkan, U., Gokbulak, F. (2017). Effect of vegetation change from forest to herbaceous vegetation cover on soil moisture and temperature regimes and soil water chemistry. Catena , 149, 158-166.

Piotrowska, A.(2014). Enzymes and Soil Fertility ; OMICS eBook Group: Foster, USA, 44-79.

Prescott, C. E. (2010). Litter decomposition: what controls it and how can we alter it to sequester more carbon in forest soils? Biogeochemistry, 101 (1-3), 133-149. doi:10.1007/s10533-010-9439-0

Qi, R., Li, J., Lin, Z., Li, Z., Li, Y., Yang, X., . . . Zhao, B. (2016). Temperature effects on soil organic carbon, soil labile organic carbon fractions, and soil enzyme activities under long-term fertilization regimes. Applied Soil Ecology, 102 , 36-45. doi:10.1016/j.apsoil.2016.02.004

Qiao, Y., Miao, S., Silva, LCR., Horwath, WR. (2014). Understory species regulate litter decomposition and accumulation of $\mathrm{C}$ and $\mathrm{N}$ in forest soils: A long-term dual-isotope experiment. Forest ecology and management, 329, 318-327.

Ran, L., Lu, X., \& Xu, J. (2013). Effects of Vegetation Restoration on Soil Conservation and Sediment Loads in China: A Critical Review.Critical Reviews in Environmental Science and Technology, 43 (13), 1384-1415. doi:10.1080/10643389.2011.644225

Roldan, A., Salinas-Garcia, J. R., Alguacil, M. M., \& Caravaca, F. (2005). Changes in soil enzyme activity, fertility, aggregation and $\mathrm{C}$ sequestration mediated by conservation tillage practices and water regime in a maize field. Applied Soil Ecology, 30 (1), 11-20. doi:10.1016/j.apsoil.2005.01.004

Ruan, C., Li, D. (2002). Function and benefit of Hippophae rhamnoides L. improving eco-environment of Loess Plateau of China. In 12th ISCO Conference, Beijing, China.

Sahoo, U. K., Singh, S. L., Gogoi, A., Kenye, A., \& Sahoo, S. S. (2019). Active and passive soil organic carbon pools as affected by different land use types in Mizoram, Northeast India. PLoS One, 14 (7), e0219969. doi:10.1371/journal.pone.0219969

Sharma, B., Gupta, R., Sahoo, D. and Deswal, R., 2019. Purification of dual-functioning chitinases with hydrolytic and antifreeze activities from Hippophae rhamnoides seedlings. Journal of Proteins and Proteomics , 10(1), 69-81.

Simard D. G., Fyles J. W., D. Pare., \& Nguyen, T. (2001). Impacts of clearcut harvesting and wildfire on soil nutrient status in the Quebec boreal forest. Canadian Journal of Soil Science ,81, 229-237.

Singh, D. K., \& Kumar, S. (2008). Nitrate reductase, arginine deaminase, urease and dehydrogenase activities in natural soil (ridges with forest) and in cotton soil after acetamiprid treatments. Chemosphere, 71 (3), 412 418. doi:10.1016/j.chemosphere.2007.11.005

Sistla, S.A., Asao, S. \& Schimel, J.P. (2012). Detecting microbial N-limitation in tussock tundra soil: implications for Arctic soil organic carbon cycling. Soil Biology and Biochemistry, 55, 78-84. 
Sollins, P., Swanston, C., Kramer, M. (2007). Stabilization and destabilization of soil organic matter-a new focus.Biogeochemistry , 85, 1-7.

Solomon, D., Lehmann, J., Kinyangi, J., Amelung, W., Lobe, I., Pell, A., . . . SchAFer, T. (2007). Long-term impacts of anthropogenic perturbations on dynamics and speciation of organic carbon in tropical forest and subtropical grassland ecosystems. Global Change Biology, 13 (2), 511-530. doi:10.1111/j.13652486.2006.01304.x

Soucemarianadin, L.N., Cecillon, L., Guenet, B., Chenu, C., Baudin, F., Nicolas, M., Girardin, C. and Barre, P. (2018). Environmental factors controlling soil organic carbon stability in French forest soils.Plant and Soil , 426(1-2), 267-286.

Sun, L., Hu, T., Kim, J. H., Guo, F., Song, H., Lv, X., \& Hu, H. (2014). The effect of fire disturbance on short-term soil respiration in typical forest of Greater Xing'an Range, China. Journal of Forestry Research, 25 (3), 613-620. doi:10.1007/s11676-014-0499-1

Thorburn, P. J., Meier, E. A., Collins, K., \& Robertson, F. A. (2012). Changes in soil carbon sequestration, fractionation and soil fertility in response to sugarcane residue retention are site-specific. Soil and Tillage Research, 120 , 99-111. doi:10.1016/j.still.2011.11.009

Vance, E. D., Brookes, P. C., Jenkinson, D. S. (1987).An extraction method for measuring soil microbial biomass C. Soil Biology \& Biochemistry, 19, 703-707.

Wei, E., Yang, R., Zhao, H., Wang, P., Zhao, S., Zhai, W., Zhang, Y. and Zhou, H. (2019). Microwaveassisted extraction releases the antioxidant polysaccharides from seabuckthorn (Hippophae rhamnoides L.) berries.International journal of biological macromolecules , 123, 280-290.

Weintraub, M. N., Scott-Denton, L. E., Schmidt, S. K., \& Monson, R. K. (2007). The effects of tree rhizodeposition on soil exoenzyme activity, dissolved organic carbon, and nutrient availability in a subalpine forest ecosystem. Oecologia, 154 (2), 327-338. doi:10.1007/s00442-007-0804-1

Xiao, Y., Huang, Z., \& Lu, X. (2015). Changes of soil labile organic carbon fractions and their relation to soil microbial characteristics in four typical wetlands of Sanjiang Plain, Northeast China.Ecological Engineering, 82, 381-389. doi:10.1016/j.ecoleng.2015.05.015

Xie, X., Pu, L., Wang, Q., Zhu, M., Xu, Y. and Zhang, M. (2017). Response of soil physicochemical properties and enzyme activities to long-term reclamation of coastal saline soil, Eastern China.Science of the total environment, 607, 1419-1427.

Xu, X., Shi, Z., Li, D., Rey, A., Ruan, H., Craine, J. M., . . . Luo, Y. (2016). Soil properties control decomposition of soil organic carbon: Results from data-assimilation analysis. Geoderma, 262 , 235-242. doi:10.1016/j.geoderma.2015.08.038

Xun, L., Feng-Min, L., Da-Qian, L., \& Guo-Jun, S. (2010). Soil organic carbon, carbon fractions and nutrients as affected by land use in semi-arid region of Loess Plateau of China. Pedosphere , 20(2), 146-152.

Yang, X., Wang, D., Lan, Y., Meng, J., Jiang, L., Sun, Q., Cao, D., Sun, Y. and Chen, W. (2018). Labile organic carbon fractions and carbon pool management index in a 3-year field study with biochar amendment.Journal of soils and sediments , 18(4), 1569-1578.

Yang, Y., Guo, J., Chen, G., Yin, Y., Gao, R., \& Lin, C. (2009). Effects of forest conversion on soil labile organic carbon fractions and aggregate stability in subtropical China. Plant and Soil, 323 (1-2), 153-162. doi:10.1007/s11104-009-9921-4

Yin, R.; Deng, H.; Wang, H. L.; Zhang, B.(2014).Vegetation type affects soil enzyme activities and microbial functional diversity following re-vegetation of a severely eroded red soil in sub-tropical China. Catena, 115, 96-103. 
Zhang, X., Song, Z., Hao, Q., Wang, Y., Ding, F., \& Song, A. (2019). Phytolith-Occluded Carbon Storages in Forest Litter Layers in Southern China: Implications for Evaluation of Long-Term Forest Carbon Budget.Front Plant Sci, 10 , 581. doi:10.3389/fpls.2019.00581

Zhang, Z.S., Li, X.R., Liu, L.C., Jia, R.L., Zhang, J.G. and Wang, T. (2009). Distribution, biomass, and dynamics of roots in a revegetated stand of Caragana korshinskii in the Tengger Desert, northwestern China.Journal of plant research , 122(1), 109-119.

Zhao, D., Li, F., \& Wang, R. (2012). The effects of different urban land use patterns on soil microbial biomass nitrogen and enzyme activities in urban area of Beijing, China. Acta Ecologica Sinica, 32 (3), 144-149. doi:10.1016/j.chnaes.2012.04.005

Zhao, S., Li, K., Zhou, W., Qiu, S., Huang, S., \& He, P. (2016). Changes in soil microbial community, enzyme activities and organic matter fractions under long-term straw return in north-central China.Agriculture, Ecosystems \& Environment, 216 , 82-88. doi:10.1016/j.agee.2015.09.028

Table 1. The basic information of different vegetation types

\begin{tabular}{|c|c|c|c|}
\hline Vegetation & Main species & Coverage/\% & Plants height $/ \mathrm{m}$ \\
\hline $\mathrm{XS}$ & $\begin{array}{l}\text { Xanthoceras sorbifolia, } \\
\text { Agropyron cristatum } \\
\text { (Linn.) Gaertn, } \\
\text { Bupleurum chinense) }\end{array}$ & 60 & 6 \\
\hline $\mathrm{HR}$ & $\begin{array}{l}\text { Hippophae rhamnoides, } \\
\text { Medicago sativa, } \\
\text { Agropyron cristatum } \\
\text { (Linn.) Gaertn }\end{array}$ & 85 & 0.6 \\
\hline CK & $\begin{array}{l}\text { Caragana korshinskii, } \\
\text { Agropyron cristatum } \\
\text { (Linn.) Gaertn }\end{array}$ & 30 & 1 \\
\hline GL & $\begin{array}{l}\text { Agropyron cristatum } \\
\text { (Linn.) Gaertn, } \\
\text { Artemisia frigida } \\
\text { Willd.Sp.Pl., Stipa } \\
\text { grandis P.Smirn. }\end{array}$ & $>90$ & 0.2 \\
\hline
\end{tabular}

XS: Xanthoceras sorbifolia ; HR: Hippophae rhamnoides ; CK:Caragana korshinskii ; GL: Grassland.

Table 2. Basic properties of the soils for the four vegetation types.

\begin{tabular}{llllll}
\hline Vegetation & soil layers $(\mathbf{c m})$ & Bulk density $\left(\mathrm{g} / \mathbf{c m}^{\mathbf{3}}\right)$ & Total porosity $(\mathbf{\%})$ & Total $\mathbf{~}(\mathrm{g} / \mathbf{k g})$ & Total P $(\mathbf{m g} / \mathbf{k}$ \\
\hline $\mathrm{XS}$ & $0-20$ & $1.54 \pm 0.02 \mathrm{AB}$ & $67.38 \pm 1.67 \mathrm{~A}$ & $\mathbf{0 . 6 6} \pm \mathbf{0 . 0 0} \mathbf{A}$ & $\mathbf{4 3 . 1 5} \pm \mathbf{0 . 7 5} \mathbf{A}$ \\
& $20-40$ & $1.66 \pm 0.02 \mathrm{~A}$ & $56.17 \pm 1.10 \mathrm{BC}$ & $0.33 \pm 0.00 \mathrm{~A}$ & $30.56 \pm 0.97 \mathrm{~B}$ \\
$\mathrm{HR}$ & $0-20$ & $1.58 \pm 0.02 \mathrm{~A}$ & $62.46 \pm 0.61 \mathrm{~A}$ & $0.43 \pm 0.00 \mathrm{~B}$ & $42.13 \pm 0.49 \mathrm{~A}$ \\
& $20-40$ & $1.65 \pm 0.06 \mathrm{~A}$ & $\mathbf{6 6 . 4 1} \pm \mathbf{1 . 6 5} \mathbf{A}$ & $0.37 \pm 0.04 \mathrm{~A}$ & $32.32 \pm 1.00 \mathrm{AB}$ \\
$\mathrm{CK}$ & $0-20$ & $1.50 \pm 0.03 \mathrm{~B}$ & $67.33 \pm 1.01 \mathrm{~A}$ & $0.39 \pm 0.00 \mathrm{C}$ & $33.76 \pm 0.12 \mathrm{C}$ \\
& $20-40$ & $1.56 \pm 0.08 \mathrm{~A}$ & $63.00 \pm 3.31 \mathrm{AB}$ & $0.31 \pm 0.00 \mathrm{~A}$ & $32.45 \pm 0.36 \mathrm{AB}$ \\
$\mathrm{GL}$ & $0-20$ & $\mathbf{1 . 5 9} \pm \mathbf{0 . 0 2} \mathbf{A}$ & $67.06 \pm 2.43 \mathrm{~A}$ & $0.40 \pm 0.01 \mathrm{C}$ & $37.44 \pm 0.48 \mathrm{~B}$ \\
& $20-40$ & $\mathbf{1 . 7 1} \pm \mathbf{0 . 0 2} \mathbf{A}$ & $54.59 \pm 2.31 \mathrm{C}$ & $0.33 \pm 0.01 \mathrm{~A}$ & $\mathbf{3 4 . 6 3} \pm \mathbf{0 . 1 3} \mathrm{A}$ \\
\hline
\end{tabular}

XS: Xanthoceras sorbifolia ; HR: Hippophae rhamnoides ; CK:Caragana korshinskii ; GL: Grassland. Capital 
letters indicate that there are significant differences $(\mathrm{P}<0.05)$ between vegetation types under the same soil layer $(\mathrm{n}=12)$. The error is the standard error.

Table 3. Two-factor ANOVA analysis was used to test the differences in soil organic carbon components (microbial biomass carbon, MBC; easily oxidized carbon, EOC; particulate organic carbon, POC; soil organic carbon, SOC) and enzyme activities (amylase; catalase; urease; invertase). VT: vegetation type, SD: soil depth.

\begin{tabular}{|c|c|c|c|c|c|c|c|c|c|}
\hline & MBC & MBC & MBC & EOC & EOC & EOC & POC & POC & POC \\
\hline & $\mathrm{df}$ & $\mathrm{F}$ & $\mathrm{P}$ & $\mathrm{df}$ & $\mathrm{F}$ & $\mathrm{P}$ & $\mathrm{df}$ & $\mathrm{F}$ & $\mathrm{P}$ \\
\hline VT & 3 & 33.210 & .000 & 3 & 298.827 & .000 & 3 & 17.438 & .000 \\
\hline SD & 1 & 65.499 & .000 & 1 & 2320.578 & .000 & 1 & 449.429 & .000 \\
\hline \multirow{3}{*}{$\mathbf{V T} \times \mathbf{S D}$} & 3 & 15.946 & .000 & 3 & 61.852 & .000 & 3 & 37.881 & .000 \\
\hline & Amylase & Amylase & Amylase & Catalase & Catalase & Catalase & Urease & Urease & Urease \\
\hline & df & $\mathrm{F}$ & $\mathrm{P}$ & df & $\mathrm{F}$ & $\mathrm{P}$ & df & $\mathrm{F}$ & $\mathrm{P}$ \\
\hline VT & 3 & 13.920 & .000 & 3 & 1.260 & .321 & 3 & 1964.539 & .000 \\
\hline SD & 1 & 93.711 & .000 & 1 & 0.222 & .644 & 1 & 10051.341 & .000 \\
\hline $\mathbf{V T} \times \mathbf{S D}$ & 3 & 7.227 & .003 & 3 & 4.398 & .019 & 3 & 712.897 & .000 \\
\hline
\end{tabular}

Table 4. The correlation coefficients between soil labile organic carbon and enzyme activities

\begin{tabular}{|c|c|c|c|c|c|c|c|c|c|}
\hline Correlation coefficients & MBC & EOC & POC & SOC & Amylase & Catalase & Urease & Sucrase & Total N \\
\hline MBC & 1 & $-.911^{* *}$ & $.596^{*}$ & -.136 & .206 & $.694 *$ & -.197 & -.154 & -.117 \\
\hline EOC & & 1 & -.378 & .459 & -.254 & -.485 & .487 & .347 & .423 \\
\hline POC & & & 1 & $.591^{*}$ & .492 & .518 & $.582^{*}$ & $.629 *$ & $.629^{*}$ \\
\hline $\mathrm{SOC}$ & & & & 1 & .069 & .317 & $.984^{* *}$ & $.767^{* *}$ & $.990^{* *}$ \\
\hline Amylase & & & & & 1 & -.258 & .198 & $.597^{*}$ & .130 \\
\hline Catalase & & & & & & 1 & .197 & -.145 & .320 \\
\hline Urease & & & & & & & 1 & $.848^{* *}$ & $.980^{* *}$ \\
\hline Surase & & & & & & & & 1 & $.776^{* *}$ \\
\hline Total N & & & & & & & & & 1 \\
\hline \multicolumn{10}{|l|}{ Total P } \\
\hline \multicolumn{10}{|l|}{ Total porosity } \\
\hline Bulk density & & & & & & & & & \\
\hline
\end{tabular}

MBC: microbial biomass carbon; EOC: easily oxidized carbon; POC: particulate organic carbon; SOC: soil organic carbon. **: Significant relation at 0.01 levels; *: Significant relation at 0.05 levels. 


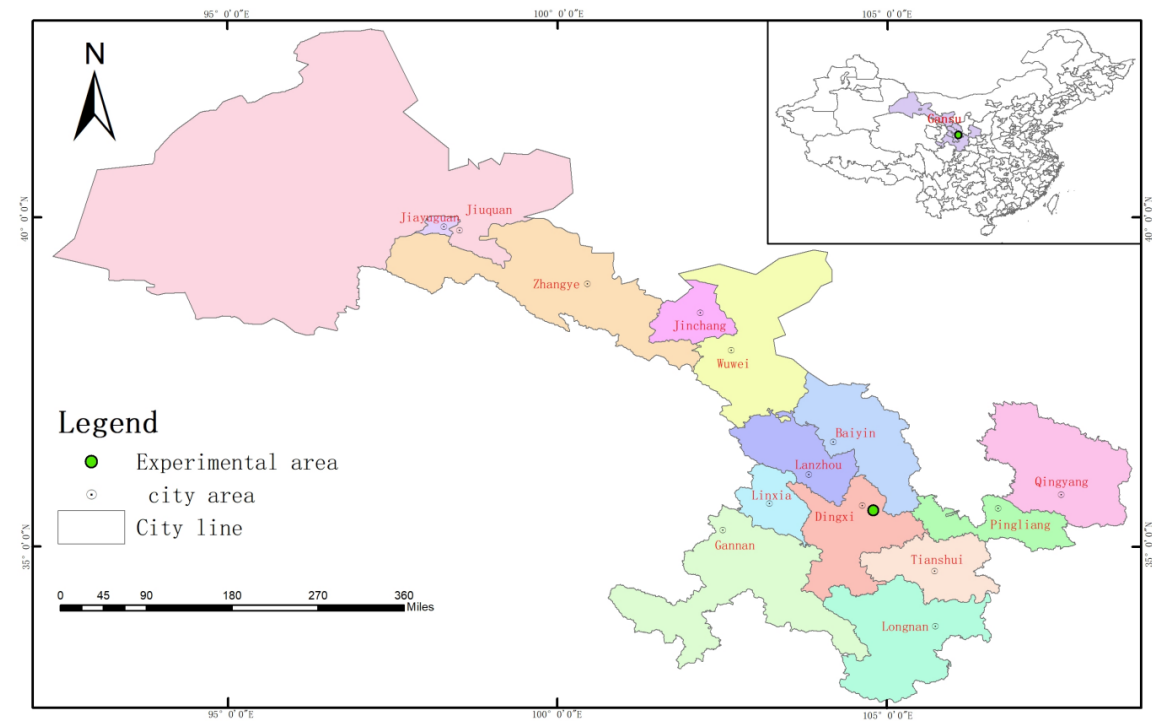

Figure 1. The geographical location map of the study area.

Figure 2. Vegetation type affects MBC (A; microbial biomass carbon), EOC (B; easily oxidized carbon), POC (C; particulate organic carbon) and SOC (D; soil organic carbon) content. XS: Xanthoceras sorbifolia ; HR: Hippophae rhamnoides ; CK: Caragana korshinskii ; GL: Grassland. Capital letters indicate significant differences $(\mathrm{P}<0.05)$ between vegetation types. The error bar is the standard error.

Figure 3. Vegetation type affects soil amylase (A), catalase (B), urease (C) and sucrase (D) activity. XS: Xanthoceras sorbifolia ; HR: Hippophae rhamnoides ; CK: Caragana korshinskii ; GL: Grassland. Capital letters indicate significant differences $(\mathrm{P}<0.05)$ between vegetation types. The error bar is the standard error.

\section{Hosted file}

Figure.doc available at https://authorea.com/users/318955/articles/462661-changes-in-soilcarbon-fractions-and-enzyme-activities-under-different-vegetation-types-of-the-northernloess-plateau 